Original Article

\title{
STUDIES ON NUTRITIONAL PROFILE AND ANTIOXIDANT POTENTIAL OF DIFFERENT DIOSCOREA SP WITH PLECTRANTHUS ROTUNDIFOLIUS
}

\author{
JENIT K. JOY, P. SIDDHURAJU* \\ Bioresource Technology Lab, Department of Environmental Sciences, School of Life Sciences, Bharathiar University, Coimbatore 641046, \\ Tamil Nadu, India \\ Email: psiddhuraju@buc.edu.in
}

Received: 27 Jan 2017, Revised and Accepted: 20 Apr 2017

\begin{abstract}
Objective: Protection from oxidative damage to the tissues is provided by natural or synthetic antioxidants. Because of the multiple mechanisms of actions and presence of various phytochemicals, plant-based antioxidants are preferred. Dioscorea is well known as a traditional edible tuber. The present study was undertaken to explore and highlights the nutritional benefits and to evaluate the in vitro antioxidant and free radical scavenging capacity of ethanolic extract of three different underutilised Dioscorea species (D. alata, D. pentaphylla and D. oppositifolia) with a common cultivated crop, Plectranthus rotundifolius.
\end{abstract}

Methods: Different processing methods are adopted to assess their influence on nutritive value and antioxidant properties. Tubers were studied for proximate composition using standard analytical methods. Mineral elements were analysed using ICP-MS (Inductively Coupled Plasma-Mass Spectrometer). Antioxidant potential of raw and processed samples was determined using a range of in vitro models.

Results: The presence of essential minerals such as $\mathrm{Na}, \mathrm{K}, \mathrm{Ca}, \mathrm{P}, \mathrm{Zn}$ and $\mathrm{Mn}$ were observed. High radical scavenging activity was observed in the tubers of Dioscorea. Results indicated that phenolic compounds are the significant contributors to the antioxidant activity.

Conclusion: Current study suggests that Dioscorea might be a promising natural antioxidant and could be very useful health food, as they enhance the antioxidant defence system. It also proposes that underutilized tubers can efficiently contribute to the nutritional requirement and food security.

\section{Keywords: Yam, Dioscorea, Plectranthus rotundifolius, Antioxidant activity}

(c) 2017 The Authors. Published by Innovare Academic Sciences Pvt Ltd. This is an open access article under the CC BY license (http://creativecommons.org/licenses/by/4.0/) DOI: http://dx.doi.org/10.22159/ijcpr.2017v9i4.20959

\section{INTRODUCTION}

Roots and tubers have always been critical components in the diet during the early evolution of mankind and they were the most important food crops of very ancient origin, always associated with human existence and survival, and allowing human socio-economic history [1]. Root crops constitute a dominant portion of a standard diet for people of the tropics and sub-tropics, with yams being the most prized crop. Yam is the common name of rhizomes of the Dioscorea species, have been consumed as staple food and used for various disorders. They are angiosperms and a member of the monocotyledonous family, Dioscoreaceae. The genus Dioscorea comprising over 650 species distributed throughout the World's tropical, subtropical and temperate regions [2-3]. The Dioscorea genus includes an important group of tropical food yams, the edible portion of which is the tuber, and occasionally the bulbil. Yam and cassava are tropical crops that are used as energy-rich staple foods and are widely consumed in Asia, Africa, and South America [4-5]. Although the New World crops of cassava and sweet potato have overtaken yams in range and volume, they remain as a dominant crop in the regions where they are best adapted.

Yam is a highly nutritional produce attributed to its functional components. It is largely consumed due to its nutritional values and unique taste. It is suggested that dioscorin, the storage protein of yam tuber, may play a role as antioxidant in tubers and beneficial for health when people take it as a food additive or consume yam tubers [6]. Recent researchers have also found that dioscorin might be exhibit antihypertensive, immuno-modulatory and lectin activities and can protect airway epithelial cells against dust mite allergen destruction and scavenging DPPH and hydroxyl free radicals [7-8]. Different species of Dioscorea have been widely used for enhancement of health in Eastern countries and listed as a superior medical herb substance. Other uses of yam include the production of local beer from flours of detoxified poisonous varieties [9], and feeding of yam peels to ruminant livestock.

Reactive oxygen species (ROS) are highly reactive molecules, initially considered as damaging agents in living organisms. Free radicals are a common outcome of normal aerobic cellular metabolism [10]. ROS and free radicals are toxic, mostly owing to direct damage of sensitive and biologically significant targets, and are thus a major cause of oxidative stress. They may attack life-important molecules such as DNA and membrane lipids. When our protein-controlled antioxidant-response doesn't keep up oxidative stress, it causes oxidative damage and also has an impact on the body's aging process. If the rate of free radical generation goes beyond that of degradation under environmental stresses, it will end into a range of disorders such as Alzheimer's disease, Parkinson's disease and many other neural disorders [10].

Antioxidants are man-made or natural substances that inhibit or quench free radical reactions and delay or inhibit cellular damage [11]. Antioxidants exert their effects through several basic mechanisms, which include: scavenging the species that initiate peroxidation, quenching singlet oxygen, chelating metals, breaking free radical chain reactions, and reducing the concentration of $\mathrm{O}_{2}$ [12]. It is possible to reduce the risk of chronic disorders and prevent the disease progression by either enhancing the body's natural antioxidant defence or supplementing with proven antioxidants. In recent years, the possible toxicity of synthetic chemical antioxidants has been criticized [13]. Therefore, the discovery of natural antioxidants is a major thrust area [14].

Antioxidant capacity is widely used as a parameter to characterize nutritional health food or plants and their bioactive components. Dietary antioxidants may be effective in the prevention of oxidative damage. Many scientists have focused on medicinal and edible plants to discover natural antioxidants since some synthetic 
antioxidants have toxic effects. In addition, natural antioxidants may have an important role in protecting human health [14-15]. Increasing evidence put forward that majority of the bioactive and phytochemical components in plants impart physiological activities and can offer various health advantages, for example, antioxidant, antibacterial and anti-inflammatory activity [16]. Growing requirement for dietary antioxidant sources has generated the exploration of novel and cost-effective bio-resources that are fulfilling several functions, and also has the free radical scavenging potential [17]. Thus, current studies have investigated the potential of plant products to serve as antioxidants to protect against various diseases induced by free radicals.

Across the world, many of the plant species that are cultivated for food are neglected and underutilized while they play a crucial role in the food security, nutrition, and income generation of the rural poor [18]. Indigenous crops are in danger of being replaced by few cultivated species and they remain inadequately characterized and neglected by research and conservation. Lack of attention has meant that their potential value is underestimated and underexploited. It also places them in danger of continued genetic erosion and disappearance which would further restrict development options for the poor. Many neglected and underutilized crop species (NUCS) are nutritionally rich [19-21], therefore, their erosion can have immediate consequences on the nutritional status and food security of the poor and their enhanced use can bring about better nutrition and to fight hidden hunger. They complement significantly the diet based on few staple crops by providing important vitamins and minerals. Underutilized species hold great genetic diversity, and a vast heritage of indigenous knowledge is linked to these species [19, 22]. Farmers and forest inhabitants or tribal people are the source of information for revealing the potentials of these species, their distribution and local use.

Under the overarching goals of food security, poverty elimination and environmental sustainability, underutilized species should be selected on the basis of their capacity to best address such challenges. Underutilized species offer untapped potentials to contribute to fight malnutrition. Multiple uses offer greater opportunities to raise the income of local people by diversifying valuable plant products. Yams were among the first plants to be cultivated deliberately by humans, yet they remain among the least altered by the process of domestication. Despite being the tenth most important starchy staple in the world in terms of production volume [23], yams remain little studied and poorly understood. If properly promoted, these crops have the potential to make a much stronger contribution to the development of poor communities, especially in the context of current and emerging global challenges for agriculture caused by climate change, population growth and other factors. Effective use of the genetic resources of underutilized species can also help to increase awareness of their value and promote efforts to conserve them.

Yams could be used to develop functional antioxidant-rich foods. In spite of an increasing interest in yam, published data on the antioxidative effect of the locally grown yams are sparse. The antioxidant activity of Dioscorea is still unknown, although it has been reported in some species. Tubers have an immense potential as functional foods and nutraceutical ingredients to be explored in disease risk reduction and wellness. In recent years, healthconscious consumers have increasingly been seeking functional foods in an effort to control their own health and well-being. For these reasons, this paper deals with the antioxidative activity and contribution to the nutritional significance of the ethanolic extracts of different Dioscorea sp to understand their role as a functional food.

There is a lack of information available on the wild yam species which can be an alternative food resource and having various bioactive components with promising properties. The present study has, therefore, been conducted (a) to evaluate antioxidant capacity of scavenging ABTS radical cation and DPPH-radical, Ferric Reducing Antioxidant Power and Metal chelating activity, and the influences of indigenous processing techniques such as boiling, steaming and roasting; and (b) to determine the proximate and mineral composition of different Dioscorea sp with commodity crop, Pl. rotundifolius. Findings from this first round investigation might offer innovative ideas about antioxidant activity of the plants which may be useful in developing value-added foods.

The knowledge about this underutilised resource on its medicinal applications and food usage is been diminished from our ancestors, as on change in lifestyle. However, a greater part of its neglect is probably due to the poor returns on past research effort, as many distinctive features of the crop pose challenging barriers to research for both genetic and agronomic improvement. The motivation for studying these underutilized tuber crops is their conservation as great genetic diversity, diverse sources of phytochemicals, agronomic and economic advancement and a vast heritage of indigenous knowledge. It is hoped that this study will help to develop Dioscorea as functional antioxidant-rich foods and to determine the possibility of using it for human consumption.

\section{MATERIALS AND METHODS}

\section{Chemicals and Instruments}

Folin-ciocalteu reagent, Sodium carbonate, Poly (vinyl-poly pyrrolidone), Sodium nitrite, Aluminium chloride, Sodium hydroxide, Ferric chloride, 2,2'-diphenyl-1-picrylhydrazyl (DPPH), Potassium persulfate, 2,2-azinobis (3-ethylbenzo-thiozoline-6sulfonic acid) disodium salt (ABTS), 6-hydroxy-2,5,7,8-tetramethylchroman 2-carboxylic acid (trolox), Ferrous chloride, Ammonium thiocyanate, Hydrogen peroxide, Ferrous Ammonium Sulfate, Ethylene Diamine Tetra Acetic acid (EDTA) disodium salt and were obtained from Hi-Media, Merck and Sigma. All other reagents used were of analytical grade. All analysis was performed with UV-Visible Spectrophotometer (Cyberlab-UV 100, USA).

\section{Sample collection and identification}

The matured indigenous fresh tubers of D. alata, D. pentaphylla and $D$. Oppositifolia were gathered from Attappadi, Palakkad Dist, Kerala, during November 2014, whereas the commodity crop Pl. rotundifolius was collected from local market of Coimbatore Dist., Tamil Nadu during the same season. These plants are authenticated (No. BSI/SRC/5/23/2016/Tech./1761) in Botanical Survey of India, Southern Regional centre, Coimbatore. Samples were cleaned by removing foreign particles, immature and damaged parts were removed.

\section{Determination of physical properties}

The tubers were examined for their weight using digital balance (Sartorious, Germany). They were measured for their dimensions (cm) such as length. The physical appearance of each tuber from three Dioscorea species and Pl. rotundifolius were observed.

\section{Processing method}

The cleaned tubers of Dioscorea sp. and Pl. rotundifolius were peeled and chopped, and randomly divided into four equal parts. One part of the tubers was dried at $40^{\circ} \mathrm{C}$ in an incubator without any treatment, left as raw. The second part was boiled at $100{ }^{\circ} \mathrm{C}$ for $60 \mathrm{~min}$ in the ratio $1: 10$ $(\mathrm{w} / \mathrm{v})$. The third part of the sample was steamed at $121^{\circ} \mathrm{C}$ for $15 \mathrm{~min}$ in the ratio $1: 10(\mathrm{w} / \mathrm{v})$ and the final part was roasted at $200^{\circ} \mathrm{C}$ for $100 \mathrm{~min}$ in a hot air oven. After decanting the water, boiled and steamed samples were cooled and dried separately. The dried materials were ground (particle size of about $0.25 \mathrm{~mm}$ ) and stored for further analysis.

\section{Proximate analysis}

The Moisture content of raw and processed samples was determined using Moisture Analyzer MA35 (Sartorius AG, Germany) at $105{ }^{\circ} \mathrm{C}$. Micro-Kjeldahl method was used to determine the total nitrogen and a nitrogen-protein conversion factor $(\mathrm{N} \times 6.25)$ is used for Crude protein determination. Crude lipid (Soxhlet extraction), Crude fibre and Ash contents (Gravimetric) were also determined based on the methods outlined in Association of Official Analytical Chemists [24]. The carbohydrate (also called Nitrogen Free Extractives (NFE)) content was estimated by the percentile difference from all the other constituents. The gross energy (Kcal) was determined by multiplying the percentage of crude protein, crude lipid and NFE by 16.7, 37.7 and 16.7 respectively [25]. The proximate composition was expressed in percentage. 


\section{Mineral analysis}

Dioscorea and Pl. rotundifolius tuber samples were digested using triacid. Triacid was prepared with Nitric acid, Sulphuric acid and Perchloric acid in the ratio of 9:2:1. $10 \mathrm{ml}$ of triacid was added to $200 \mathrm{mg}$ of sample and digested at $80{ }^{\circ} \mathrm{C}$ in a fume hood. After digestion, the samples were made up to $100 \mathrm{ml}$ with distilled water (HPLC Grade). 3-4 $\mathrm{ml}$ of samples were used to analyze all the 17 minerals through the ICP-MS (Nex Ion $300 \mathrm{X}$, Perkin Elmer, USA). Calcium was determined using Flame photometric analysis.

\section{Solvent extraction}

The dried coarse powder of tubers was subjected to ethanolic extraction in the ratio of water: alcohol. The raw and processed samples $(15 \mathrm{~g})$ were extracted with $95 \%$ ethanol $(1: 7 \mathrm{w} / \mathrm{v})$ by occasional stirring for $48 \mathrm{~h}$ at room temperature. The extracts were filtered and pooled. The filtrates were re-extracted with the solvent $(1: 5 \mathrm{w} / \mathrm{v})$ for $24 \mathrm{~h}$ at room temperature and filtering through WhatmannNo.4 filter paper. Both the extracts were mixed. The solvent of pooled extracts was evaporated under the low temperature at $40{ }^{\circ} \mathrm{C}$ in incubator (NSW, New Delhi) and stored in a refrigerator. The extract gained was used for further analysis and the percentage of recovery was calculated by the following equation:

$$
\text { Recovery } \%=\frac{[(\text { Extract }+ \text { container weight }(\mathrm{g}))-\text { Empty container }(\mathrm{g})]}{\text { Sample weight }(\mathrm{g})} \times 100
$$

\section{Estimation of total phenolics and tannins}

Total phenolic content was estimated using the Folin-Ciocalteu method [26]. The total phenolics and tannins were quantified as tannic acid equivalents (TAE) [27] from tannic acid standard curve (3-15 $\mu \mathrm{g}$ range). For the test, aliquots $(100 \mu \mathrm{l})$ of extracts were taken in test tubes and the volume was made up to $1 \mathrm{ml}$ with distilled water. Then $0.5 \mathrm{ml}$ of Folin-Ciocalteau Phenol reagent (1:1 with water) and $2.5 \mathrm{ml}$ of sodium carbonate solution $(20 \% \mathrm{w} / \mathrm{v})$ were added consecutively to each tube. Later on swirling the reaction mixture, test tubes were placed in the dark for $40 \mathrm{~min}$ and the absorbance was recorded at $725 \mathrm{~nm}$ against the reagent blank. For tannin estimation, the sample extracts were treated with $100 \mathrm{mg}$ of polyvinyl poly pyrrolidone (PVPP) and incubated at $4{ }^{\circ} \mathrm{C}$ for $4 \mathrm{~h}$. Then the samples were centrifuged at $3000 \mathrm{rpm}$ and the supernatant was collected. This supernatant comprised only with simple phenolics other than tannins (tannins would have been precipitated along with PVPP). Then using this supernatant, tannins were estimated by the same method as phenolics. The analysis was carried out in triplicate and the phenolics and tannins were expressed as mg tannic acid equivalents (TAE)/g extract. The tannin content of the samples was determined as follows:

Tannin (\%) = Total phenolics (\%)-Non-tannin phenolics (\%)

\section{Estimation of flavonoids}

$1 \mathrm{ml}$ aliquot of a standard solution of Rutin at different concentrations $(0-100 \mathrm{mg} / \mathrm{l}$, external calibration with $\mathrm{n}=6$ concentrations) or sample was added to $10 \mathrm{ml}$ volumetric flasks containing $4 \mathrm{ml}$ of water. At the beginning of the experiment, $0.3 \mathrm{ml}$ of $5 \%$ sodium nitrite was added to the flask. After $5 \mathrm{~min}, 3 \mathrm{ml}$ of $10 \%$ aluminium chloride solution was added. At $6 \mathrm{~min}, 2 \mathrm{ml}$ of $1 \mathrm{~mol} / \mathrm{l}$ sodium hydroxide was added to the mixture. Instantly, the solution was diluted to a final volume of $10 \mathrm{ml}$ with water and mixed systematically. The absorbance was measured at $510 \mathrm{~nm}$ against the prepared blanks with UV-Visible Spectrophotometer. Total flavonoid content was expressed as mg rutin (RUT)/g extract [28].

\section{Total antioxidant activity assay by radical cation (ABTS++)}

ABTS assay was based on the previous method [29] with slight modification. ABTS was dissolved in water to a $7 \mathrm{mmol} / \mathrm{l}$ concentration. ABTS stock solution reacts with $2.45 \mathrm{mmol} / \mathrm{l}$ Potassium persulfate (final concentration) to produce ABTS radical cation $\left(\mathrm{ABTS}^{-+}\right.$) and lets the mixture to stand in the dark at room temperature for $12-16 \mathrm{~h}$ prior to use. Before starting the assay, the solution was diluted in ethanol (about 1:89 v/v) and equilibrated to 30 ${ }^{\circ} \mathrm{C}$ to give an absorbance of $0.70 \pm 0.020$ at $734 \mathrm{~nm}$ in a $1 \mathrm{~cm}$ cuvette. The stock solution of sample extracts in ethanol was diluted in such a way that, after the introduction of $10 \mu \mathrm{L}$ aliquot of each dilution into the assay, they produced within 20-80\% inhibition of blank absorbance. After the addition of $1 \mathrm{ml}$ of diluted ABTS solution to 10 $\mu \mathrm{L}$ of samples or Trolox standards (final concentration 0-15 $\mu \mathrm{mol} / \mathrm{l}$ ) in ethanol, OD (optical density) was taken at $30^{\circ} \mathrm{C}$ just $30 \mathrm{~min}$ after the initial mixing. Suitable solvent blanks were also run in each assay. Triplicate determinations were prepared at each dilution of standard and percentage inhibition of the blank absorbance at $734 \mathrm{~nm}$ was plotted as a function of Trolox concentration [17]. The unit of total antioxidant activity is defined as the concentration of Trolox having equivalent antioxidant activity and expressed as $\mu \mathrm{mol} / \mathrm{g}$ sample extracts using the calibration curve of trolox. Linearity range of the calibration curve was $0.25-1.25 \mathrm{mmol} / \mathrm{l}$. Results were expressed as trolox equivalent antioxidant capacity (TEAC). The total antioxidant activity of BHA (Butylated Hydroxyl Anisole), Rutin and Tannic acid were also measured by this method for comparison.

\section{Stable free radical scavenging activity using DPPH' method}

The DPPH is a stable free radical and is widely used to assess the radical scavenging activity of an antioxidant component. This method is based on the reduction of DPPH in methanol solution in the presence of a hydrogen-donating antioxidant due to the formation of the non-radical form DPPH-H [30]. The radical scavenging activity of raw and processed sample extracts, and BHA, Rutin and Tannic acid were measured with regard to hydrogen donating or radical scavenging ability, using the DPPH method [31] with minor alterations. $0.1 \mathrm{ml}$ of extract was prepared in methanol and mixed with $3.9 \mathrm{ml}$ of DPPH $\left(6 \times 10^{-5} \mathrm{~mol} / \mathrm{l}\right.$ methanol) solution. The solution was incubated at room temperature for $30 \mathrm{~min}$ and at the end of incubation period, a decrease in absorbance was determined at $515 \mathrm{~nm}$ with a spectrophotometer. Lower absorbance values of reaction mixture indicate higher free radical scavenging activity. The trolox standard was prepared in the range of $0-2.5$ $\mathrm{mmol} / \mathrm{l}$. The concentration of DPPH was calculated from trolox standard graph and expressed as mmol trolox equivalents/g extract.

\section{Ferric reducing antioxidant power (FRAP) assay}

The antioxidant ability of phenolic extracts of raw and processed samples was estimated [32]. $900 \mu \mathrm{L}$ of freshly prepared FRAP reagent incubated at $37^{\circ} \mathrm{C}$, was mixed with $90 \mu \mathrm{L}$ of distilled water and $30 \mu \mathrm{L}$ of the test sample, or methanol (for the reagent blank). The samples and reagent blank were incubated at $37^{\circ} \mathrm{C}$ for $30 \mathrm{~min}$ in a water bath. The FRAP reagent contained $2.5 \mathrm{ml}$ of $20 \mathrm{mmol} / \mathrm{l}$ TPTZ solution in $40 \mathrm{mmol} / \mathrm{l} \mathrm{HCl}$ plus $2.5 \mathrm{ml}$ of $20 \mathrm{mmol} / \mathrm{FeCl}_{3} \cdot 6 \mathrm{H}_{2} \mathrm{O}$ and $25 \mathrm{ml}$ of $0.3 \mathrm{~mol} / \mathrm{l}$ acetate buffer, $\mathrm{pH}$ 3.6. At the end of incubation, absorbance readings were taken immediately at $593 \mathrm{~nm}$ using a UV-Visible Spectrophotometer. Methanolic solutions of known Fe (II) concentration ranging from 100 to $2000 \mu \mathrm{mol} / \mathrm{l}$ $\left(\mathrm{FeSO}_{4} \cdot 7 \mathrm{H}_{2} \mathrm{O}\right)$ were used for plotting the calibration curve. The parameter Equivalent Concentration $\left(\mathrm{EC}_{1}\right)$ was defined as the concentration of antioxidant which has a ferric-TPTZ reducing ability equivalent to that of $1 \mathrm{mmol} / \mathrm{l} \quad \mathrm{FeSO}_{4} \cdot 7 \mathrm{H}_{2} \mathrm{O} . \mathrm{EC}_{1}$ was calculated as the concentration of antioxidant giving an absorbance increase in the test equal to theoretical absorbance value of a 1 mmol/l concentration of Fe (II) solution, which was determined using the related regression equation.

\section{Metal chelating activity}

$100 \mu \mathrm{L}$ of the extracts were added to $0.05 \mathrm{ml}$ of $\mathrm{FeCl}_{2}$ (2 mmol/l) solution. The reaction was initiated by the addition of $0.2 \mathrm{ml}$ of 5 $\mathrm{mmol} / \mathrm{l}$ ferrozine, and the mixture was shaken strongly and kept for standing at room temperature for $10 \mathrm{~min}$. Absorbance of the solution was then measured at $562 \mathrm{~nm}$ using a Spectrophotometer. The results were expressed as mg EDTA equivalent/g extract using the calibration curve of EDTA. Linearity range of the calibration curve was 0.5-2.5 $\mu \mathrm{g}$ [33].

\section{Statistical analysis}

The data were brought to one-way analysis of variance (ANOVA), and the significance of the difference between means was determined by Duncan's multiple-range test* using SPSS (Version 21.0, SPSS Inc., Wacker Drive, Chicago, USA). Values expressed are means of triplicate determination \pm Standard deviation. 


\section{RESULTS AND DISCUSSION}

\section{Physical parameters and general characteristics of Dioscorea} and Plectranthus tubers

For the comparison of morphological characteristics, the physical parameters of the above-mentioned tubers were described in table 1. Dioscorea sp studied were climber monocot whereas Plectranthus is a herb. All the plant species are perennial with well-developed tubers or rhizomes. They are angiosperms and dioecious plants. The plants are growing in full sunlight (around $6 \mathrm{~h}$ per day) to partial shade. Harvesting of yam tubers must be between 7 and 12 mo after planting. Plant characters show slight variation among varieties in height, tuber length, tuber fresh weight etc.

D. alata being the most largely distributed and cultivated species with a huge number of varieties. It has different common names such as Water yam and Greater yam. Water yam leaves are large, elongate, and heart-shaped. The leaves are glabrous, and twining stems which coil readily around a stake. Observed characters were similar with previous reports [34]. Tubers produced by water yams are massive. They grow rapidly near the end of growing season. Single tubers are most common, but several are possible. Tubers are branched, grow vertically, and may be deeply buried. The tuber shape is generally cylindrical. Tuber flesh is white and watery in texture. The weight of tuber is higher in D. alata $(9999.66 \mathrm{~g})$ followed by D. oppositifolia (1999.83g) and D. pentaphylla (1360.42g).

D. pentaphylla is a species in the yam family known by the common name five leaf yams. It is a spiked vine that twines counter-clockwise around other plants. The vine grows from a tuber. Tubers are long ovoid. The alternatively arranged leaves are compound, divided into 5 leaflets; hence the common name. The height of the plant is higher $(9.96 \mathrm{~m})$ than D. oppositifolia. D. oppositifolia is otherwise known as Chinese yam, prevalent for its edible tubers. The leaves are usually arranged oppositely. Tubers are spindle-shaped or cylindrical. Yams are vegetatively propagated from the tubers. Similar to the tuber weight, the length of the tuber is also higher in D. alata $(36.40 \mathrm{~cm})$.

$\mathrm{Pl}$. rotundifolius commonly known as Chinese potato. It is an aromatic plant of the mint family. It was (7.48g) differentiated from Dioscorea and it was observed as the smallest tuber among others. Tubers are egg-shaped, and flesh is creamy white in colour. The plant is cultivated for its edible tubers. Tubers are harvested about 4 to 5 mo after planting. However, Pl. rotundifolius showed lowest tuber length $(6.58 \mathrm{~cm})$ and diameter $(1.99 \mathrm{~cm})$ compare with Dioscorea, a number of tubers per plant are higher (20).

Table 1: It shows general characteristics of plant samples

\begin{tabular}{|c|c|c|c|c|c|c|c|c|c|c|c|c|c|c|}
\hline \multirow{2}{*}{$\begin{array}{l}\text { S. } \\
\text { N } \\
\text { o. }\end{array}$} & \multirow{2}{*}{$\begin{array}{l}\text { Plant } \\
\text { Name }\end{array}$} & \multirow{2}{*}{$\begin{array}{l}\text { Height } \\
\text { (m) }\end{array}$} & \multirow{2}{*}{$\begin{array}{l}\text { Morpho } \\
\text { logy }\end{array}$} & \multirow{2}{*}{$\begin{array}{l}\text { Annual/ } \\
\text { Perenni } \\
\text { al }\end{array}$} & \multirow{2}{*}{$\begin{array}{l}\text { Stem } \\
\text { Diamet } \\
\text { er }(\mathrm{cm})\end{array}$} & \multirow{2}{*}{$\begin{array}{l}\text { Sunligh } \\
\mathrm{t} \\
\text { Require } \\
\text { ment }\end{array}$} & \multirow{2}{*}{$\begin{array}{l}\text { Averag } \\
\text { e Plant } \\
\text { Lifetim } \\
\text { e }\end{array}$} & \multirow{2}{*}{$\begin{array}{l}\text { Distributio } \\
\mathrm{n} \text { in } \\
\text { Western } \\
\text { Ghats }\end{array}$} & \multicolumn{6}{|c|}{ Tuber Characters } \\
\hline & & & & & & & & & $\begin{array}{l}\text { Fresh } \\
\text { weight (g) }\end{array}$ & $\begin{array}{l}\text { Lengt } \\
\text { h } \\
(\mathrm{cm})\end{array}$ & $\begin{array}{l}\text { Diame } \\
\text { ter } \\
(\mathrm{cm})\end{array}$ & $\begin{array}{l}\text { No. of } \\
\text { Tuber } \\
\text { s per } \\
\text { Plant }\end{array}$ & $\begin{array}{l}\text { Harves } \\
\text { ting } \\
\text { Period }\end{array}$ & $\begin{array}{l}\text { Stora } \\
\text { ge } \\
\text { Durat } \\
\text { ion }\end{array}$ \\
\hline 1 & D. alata & $\begin{array}{l}29.96 \pm \\
0.05\end{array}$ & Climber & $\begin{array}{l}\text { Perenni } \\
\text { al }\end{array}$ & $\begin{array}{l}1.96 \pm 0 . \\
05\end{array}$ & $\begin{array}{l}\text { Full } \\
\text { sunlight }\end{array}$ & $\begin{array}{l}\text { Up to } 6 \\
\text { mo }\end{array}$ & $\begin{array}{l}\text { South and } \\
\text { North, } \\
\text { Eastern } \\
\text { region of } \\
\text { India }\end{array}$ & $\begin{array}{l}9999.66 \pm \\
0.57\end{array}$ & $\begin{array}{l}36.40 \\
\pm 0.79\end{array}$ & $\begin{array}{l}5.96 \pm 0 \\
.05\end{array}$ & 1 & $\begin{array}{l}\text { Sep- } \\
\text { Nov }\end{array}$ & $\begin{array}{l}2-3 \\
\text { mo }\end{array}$ \\
\hline 2 & $\begin{array}{l}D . \\
\text { pentaph } \\
\text { ylla }\end{array}$ & $\begin{array}{l}9.96 \pm 0 \\
.05\end{array}$ & Climber & $\begin{array}{l}\text { Perenni } \\
\text { al }\end{array}$ & $\begin{array}{l}1.96 \pm 0 . \\
05\end{array}$ & $\begin{array}{l}\text { Full } \\
\text { sunlight }\end{array}$ & $\begin{array}{l}\text { Up to } 6 \\
\text { mo }\end{array}$ & $\begin{array}{l}\text { South and } \\
\text { North, } \\
\text { Eastern } \\
\text { region of } \\
\text { India }\end{array}$ & $\begin{array}{l}1360.42 \pm \\
0.81\end{array}$ & $\begin{array}{l}16.83 \\
\pm 0.28\end{array}$ & $\begin{array}{l}5.49 \pm 0 \\
.41\end{array}$ & $1-3$ & $\begin{array}{l}\text { Sep- } \\
\text { Nov }\end{array}$ & $\begin{array}{l}2-3 \\
\text { mo }\end{array}$ \\
\hline 3 & $\begin{array}{l}D . \\
\text { oppositi } \\
\text { folia }\end{array}$ & $\begin{array}{l}4.96 \pm 0 \\
.05\end{array}$ & Climber & $\begin{array}{l}\text { Perenni } \\
\text { al }\end{array}$ & $\begin{array}{l}1.96 \pm 0 . \\
05\end{array}$ & $\begin{array}{l}\text { Full } \\
\text { sunlight }\end{array}$ & $\begin{array}{l}\text { Up to } 6 \\
\text { mo }\end{array}$ & $\begin{array}{l}\text { South and } \\
\text { North, } \\
\text { Eastern } \\
\text { region of } \\
\text { India }\end{array}$ & $\begin{array}{l}1999.83 \pm \\
0.28\end{array}$ & $\begin{array}{l}35.83 \\
\pm 0.28\end{array}$ & $\begin{array}{l}4.55 \pm 0 \\
.07\end{array}$ & $1-3$ & $\begin{array}{l}\text { Sep- } \\
\text { Nov }\end{array}$ & $\begin{array}{l}2-3 \\
\text { mo }\end{array}$ \\
\hline 4 & $\begin{array}{l}\text { Plec. } \\
\text { rotundif } \\
\text { olius }\end{array}$ & $\begin{array}{l}0.49 \pm 0 \\
.00\end{array}$ & Herb & $\begin{array}{l}\text { Perenni } \\
\text { al }\end{array}$ & $\begin{array}{l}2.46 \pm 0 . \\
05\end{array}$ & $\begin{array}{l}\text { Full } \\
\text { sunlight }\end{array}$ & $\begin{array}{l}3 \text { to } 7 \\
\text { mo }\end{array}$ & $\begin{array}{l}\text { Southern } \\
\text { parts of } \\
\text { India }\end{array}$ & $7.48 \pm 0.61$ & $\begin{array}{l}6.58 \pm \\
0.51\end{array}$ & $\begin{array}{l}1.99 \pm 0 \\
.05\end{array}$ & $\begin{array}{l}\text { Up to } \\
20\end{array}$ & $\begin{array}{l}\text { Sep- } \\
\text { Nov }\end{array}$ & $\begin{array}{l}2-3 \\
\text { mo }\end{array}$ \\
\hline
\end{tabular}

Each value is expressed as mean \pm Standard deviation $(n=25)$

\section{Proximate composition}

Proximate composition of the tubers of Dioscorea and Pl. rotundifolius were summarized in table 2. The parameters determined were Moisture, Ash, Crude protein, Crude lipids, Crude fibre, Carbohydrate and Energy value. There is a significant difference was observed in the parameters studied, between the species. However, conventional food processing techniques also caused a difference in all the tubers.

Moisture content is used to determine the quality of food, increase the ease with digestion, absorption and the rate at which assimilation of food takes place within the body system. The moisture content observed for dried flour of raw and processed samples are ranged from 5.36-9.70\%. There is no significant difference was observed between the three species of Dioscorea. $D$. alata was found to have the highest moisture content $(9.70 \%)$ followed by D. pentaphylla (8.69\%), D. oppositifolia (7.31\%) and Pl. rotundifolius (6.19\%). High moisture content has positive influences, which can helps to attain better activity for water dissolved enzymes and co-enzymes that are required in metabolic activities [35-36].

According to table 2, there is no significant difference in the total ash content of Dioscorea sp. It is slightly varied from $0.52-0.72 \%$ in raw tubers of Dioscorea and Pl. rotundifolius. The ash contents of processed Dioscorea sp. and Pl. rotundifolius as depicted in table 2 revealed that processing caused a decrease $(0.15-0.63 \%)$ in the ash content than corresponding raw samples. The relative concentration of ash in the samples may provide macro and micro elements for health effects in human.

Protein is an essential nutrient ranks second place after water in occupying most plentiful substance in our body. Among the raw tubers, D. alata $(7.78 \%)$ was found to have the highest content of protein followed by D. oppositifolia $(5.68 \%)$, D. pentaphylla $(5.53 \%)$ and Pl. rotundifolius (1.85\%). D. dumetorum is the most nutritious of the six yam species consumed in Ghana, and an earlier report [37] showed that it has a mean protein content of $9.6 \%$ (dry matter basis) compared to $8.2 \%$ for water yam (D. alata) and $7.0 \%$ for white yam $(D$. rotundata). Protein content achieved in this study was little lower than previous reports. The application of heat with water markedly decreases the protein content in all the raw tubers. These decreases attributed due to the diffusion of protein content into cooking water.

The crude fibre content of Dioscorea and Pl. rotundifolius tubers are ranged in 1.21-3.34\% (table 2). D. alata (3.34\%) showed the highest fibre content among other species. In all tuber sp. cooking increased the fibre content. The gain of fibre content linked with breakage of 
some glycosidic linkages and de-polimerization of dietary fibre polysaccharides [38]. Lipid content of raw tubers of $P l$. rotundifolius $(1.91 \%)$ is found to be lower than wild species of Dioscorea. Among the samples studied, lipid content was found to be higher in D. alata raw tuber $(3.20 \%)$ and the range of total lipid content observed was $1.51-3.20 \%$. General lipid loss was registered during the processing of all the species of tubers.

Starch is the main storage reserve carbohydrate found in many different plant organs especially many roots and tubers. The total content of carbohydrates/NFE in the tuber samples were ranged from 76.68 to $88.29 \%$ with variation between species/cultivars.
Processing produced the least gain of carbohydrate content in the tubers. Earlier studies also indicate that starch is the predominant fraction of the yam tuber (D. alata-70 to $80 \%$, D. vilgaris-73.9\%) dry matter $[39,40]$.

Yam is a good source of energy. The raw tubers were showed no significant variation in the gross energy values and falls in the range between 359.65 and $378.75 \mathrm{Kcal} / 100 \mathrm{~g}$.

Plant foods with above $12 \%$ energy content have been considered as a good supply of proteins [35]. The proximate compositions of all yam species were similar to previous reports [41].

Table 2: It shows proximate composition of tubers

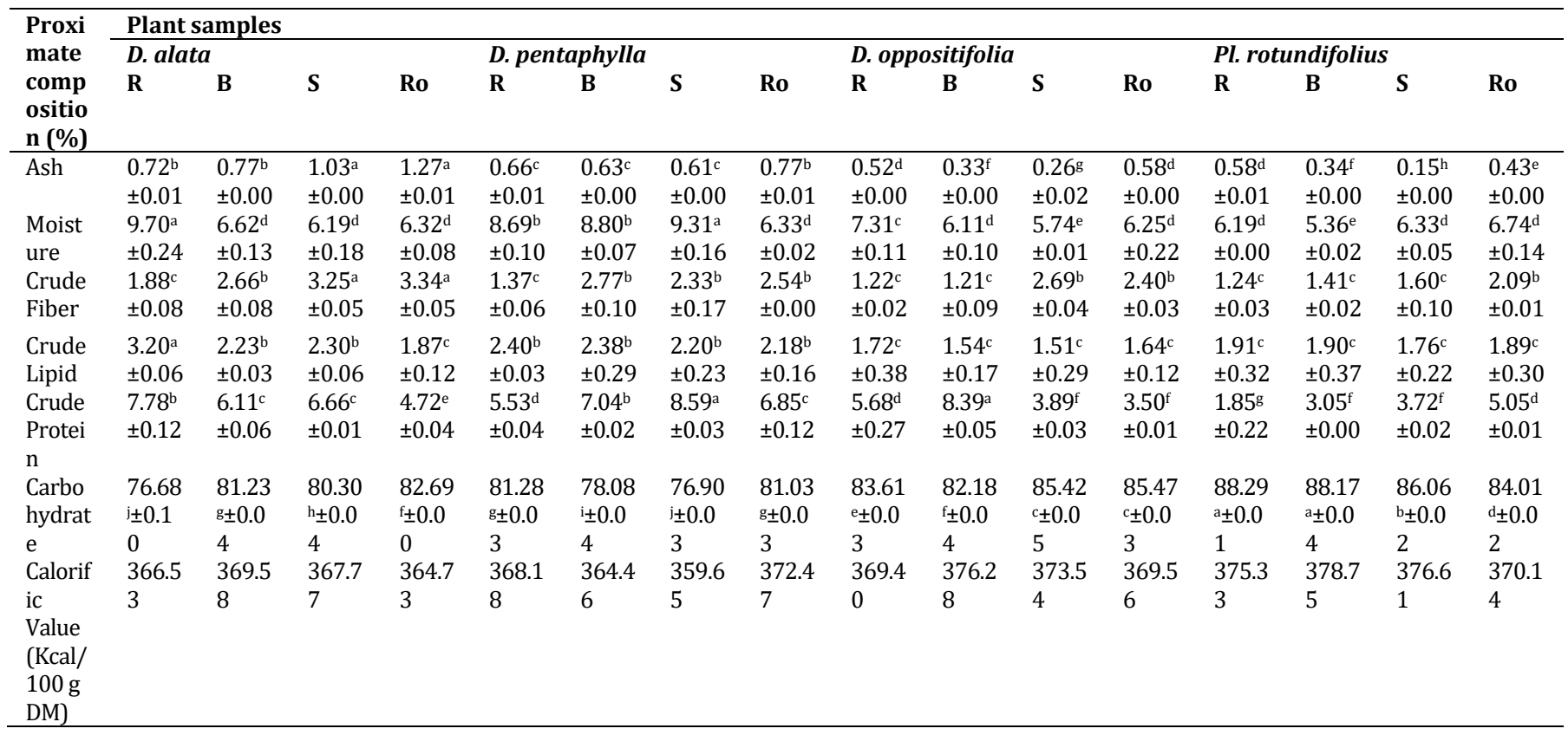

Each value is expressed as mean \pm standard deviation $(n=3)$. Mean values followed by different letters in rows are significantly different* R-Raw; B-Boiled; S-Steamed; Ro-Roasted.

\section{Mineral profile}

Minerals are fundamentally metals and other inorganic compounds that are essential for human nutrition and maintenance of certain physicochemical processes which are necessary to life. They play a critical role in the formation of skeletal structure, serving as essential co-factors for a number of enzymes and used for the utilization of nutrients and enzymes responsible for digestion and absorption [42]. Minerals are classified into three categories such as major, secondary and micro or trace minerals. $\mathrm{P}$ and $\mathrm{K}$ are major elements, $\mathrm{Ca}, \mathrm{Mg}$ and $\mathrm{S}$ are secondary and $\mathrm{B}, \mathrm{Cl}, \mathrm{Cr}, \mathrm{F}, \mathrm{I}, \mathrm{Fe}, \mathrm{Mn}, \mathrm{Mo}$, $\mathrm{Ni}, \mathrm{Se}, \mathrm{Na}, \mathrm{V}$ and $\mathrm{Zn}$ are under the category of micro, trace or rare elements. The mineral composition of raw and processed tubers of Dioscorea and Pl. rotundifolius are shown in table 3.

All the tuber species contain almost all the essential minerals for human nutrition. Dioscorea sp. is registered with the relatively higher level of major and secondary elements. Especially, D. pentaphylla registered with a higher amount of K (1402.74 mg/100g) among other species which plays a protective role against hypertension, stroke, cardiac dysfunctions, renal damage, hypercalciuria, kidney stones and osteoporosis [43]. Ca was higher in the present study for Pl. rotundifolius $(62500 \mathrm{mg} / 100 \mathrm{~g})$. On the basis of microelements, the highest concentration of $\mathrm{Fe}$ was also determined in Plectranthus (11.10 $\mathrm{mg} / 100 \mathrm{~g})$ whereas highest values of Mn (2.16 mg/100g), Zn (142.18 $\mathrm{mg} / 100 \mathrm{~g})$ and $\mathrm{Cu}(0.83 \mathrm{mg} / 100 \mathrm{~g})$ were determined in D. oppositifolious.

Mineral content may be influenced by environmental conditions such as soil composition, pH, elemental composition etc. [44]. However, processing led to considerable reduction in most of the minerals. Interestingly, processing was slightly increased the Fe levels in $D$. oppositifolia. This result is supported by a previous study [45] in that, boiling of cocoyam tubers increase the bioavailability of Fe.

Essential minerals such as $\mathrm{Fe}, \mathrm{Cu}, \mathrm{Zn}$ and $\mathrm{Mn}$ play critical functions in biological systems [46]. The results further represent that Dioscorea tubers are good sources of $\mathrm{K}, \mathrm{Mg}, \mathrm{P}$ and $\mathrm{Ca}$, whose salts regulate the acid-base balance of the body. Sodium and potassium are the main cations located within and outside the cell correspondingly and engaged in the regulation of plasma volume, muscle contraction and conduction of nerve impulse [47]. Magnesium plays a major role in relaxing muscles, prevents muscle cramps and enhances the nerve function. Fe is a key component in the human body, which performs several biochemical functions such as, infection control, cellmediated immunity and oxygen binding in haemoglobin. It can act as the main catalytic centre in various enzymes as the cytochrome oxidase [48-49]. $\mathrm{Cu}$ is a necessary micronutrient, can act as biocatalyst, and have a need for body pigmentation additionally with iron, to keep up a healthy central nervous system and prevent anemia. When considering $\mathrm{Cu}$ content in plants, most of them contain fewer amounts which are insufficient for usual development and is make sure through synthetic and inorganic fertilisers.

Phosphorus is effective in relieves bowel movement disorders like diarrhoea or constipation, maintains normal brain functions and ensures proper growth as well as cellular repair. Calcium plays a major role in bone, teeth, muscle and heart function. $\mathrm{Zn}$ is essential for nerve function, male fertility and reproduction especially in the development of testes and ovary [50]. In addition, consumption of these micro-nutrients rich foods helps to provide a strong immune system, thereby helping the body to absorb, utilize and digest required body nutrients [51]. 
Table 3: It shows mineral content of tubers

\begin{tabular}{|c|c|c|c|c|c|c|c|c|c|c|c|c|c|c|c|c|}
\hline $\begin{array}{l}\text { Mineral } \\
\text { (mg/100 } \\
\text { g) }\end{array}$ & AR & AB & AS & ARo & PR & PB & PS & PRo & OR & OB & OS & ORo & PIR & PIB & PIS & PIRo \\
\hline $\mathrm{Be}$ & 0.0005 & 0.00 & $\begin{array}{l}0.000 \\
5\end{array}$ & 0.0005 & 0.008 & 0.001 & 0.001 & 0.001 & 0.001 & 0.001 & 0.001 & 0.001 & 0.001 & 0.001 & 0.0005 & 0.001 \\
\hline $\mathrm{Na}$ & 153.11 & 24.24 & 23.69 & 32.55 & 22.62 & 181.52 & 20.77 & 176.31 & 81.79 & 775.25 & 80.08 & $\begin{array}{l}1212.1 \\
9\end{array}$ & 912.46 & 14.03 & 663.77 & 17.43 \\
\hline $\mathrm{Mg}$ & 327.84 & 32.78 & 56.51 & 63.38 & 51.28 & 176.08 & 50.74 & 180.30 & $\begin{array}{l}114.4 \\
8\end{array}$ & $\begin{array}{l}1239.7 \\
4\end{array}$ & 56.18 & 107.87 & $\begin{array}{l}1727.3 \\
4\end{array}$ & 45.33 & 496.95 & 45.32 \\
\hline $\mathrm{Al}$ & 1.58 & 1.66 & 3.36 & 6.62 & 3.67 & 5.83 & 9.71 & 3.05 & 2.09 & 2.64 & 1.89 & 153.18 & 8.36 & 2.49 & 0.22 & 2.25 \\
\hline$P$ & 85 & 137.5 & 200 & 292.50 & 95 & 385 & 95 & 170 & $\begin{array}{l}102.5 \\
0\end{array}$ & 25 & 35 & 30 & 305 & $\begin{array}{l}342.5 \\
0\end{array}$ & 97.50 & 120 \\
\hline K & $\begin{array}{l}1131.3 \\
8\end{array}$ & $\begin{array}{l}754.2 \\
4\end{array}$ & $\begin{array}{l}957.0 \\
7\end{array}$ & $\begin{array}{l}1081.9 \\
8\end{array}$ & $\begin{array}{l}1260.1 \\
3\end{array}$ & $\begin{array}{l}1084.2 \\
1\end{array}$ & $\begin{array}{l}1066.9 \\
5\end{array}$ & $\begin{array}{l}1402.7 \\
4\end{array}$ & $\begin{array}{l}515.4 \\
5\end{array}$ & 817.20 & $\begin{array}{l}367.3 \\
6\end{array}$ & 781.90 & $\begin{array}{l}3624.2 \\
9\end{array}$ & $\begin{array}{l}731.1 \\
7\end{array}$ & $\begin{array}{l}1094.4 \\
2\end{array}$ & $\begin{array}{l}959.3 \\
1\end{array}$ \\
\hline $\mathrm{Ca}$ & 60000 & $\begin{array}{l}4300 \\
0\end{array}$ & $\begin{array}{l}3900 \\
0\end{array}$ & 59500 & 57000 & 42000 & 41000 & 45500 & $\begin{array}{l}6150 \\
0\end{array}$ & 40500 & $\begin{array}{l}5600 \\
0\end{array}$ & 60000 & 62500 & $\begin{array}{l}5650 \\
0\end{array}$ & 57000 & $\begin{array}{l}5200 \\
0\end{array}$ \\
\hline $\mathrm{Cr}$ & 0.23 & 0.18 & 0.24 & 0.21 & 0.20 & 0.06 & 0.05 & 0.05 & 0.07 & 0.12 & 0.06 & 1.47 & 0.09 & 0.06 & 0.06 & 0.05 \\
\hline $\mathrm{Mn}$ & 0.34 & 0.08 & 0.12 & 0.13 & 0.15 & 0.19 & 0.14 & 0.12 & 0.22 & 2.16 & 0.10 & 1.46 & 0.51 & 0.12 & 0.26 & 0.14 \\
\hline $\mathrm{Fe}$ & 5.87 & 3.15 & 5.88 & 5.05 & 3.37 & 3.24 & 3.00 & 3.31 & 5.17 & 10.39 & 4.65 & 10.91 & 11.10 & 3.72 & 4.47 & 3.27 \\
\hline $\mathrm{Ni}$ & 0.13 & 0.07 & 0.09 & 0.08 & 0.08 & 0.03 & 0.02 & 0.03 & 0.02 & 0.10 & 0.02 & 0.63 & 0.19 & 0.04 & 0.05 & 0.25 \\
\hline $\mathrm{Cu}$ & 0.32 & 0.31 & 0.37 & 0.37 & 0.32 & 0.27 & 0.22 & 0.20 & 0.19 & 0.17 & 0.17 & 0.83 & 0.16 & 0.16 & 0.05 & 0.25 \\
\hline $\mathrm{Zn}$ & 22.02 & 1.83 & 3.80 & 9.50 & 3.59 & 6.44 & 2.32 & 10.94 & 10.03 & 142.18 & 1.33 & 11.16 & 31.49 & 1.50 & 1.31 & 1.72 \\
\hline As & 0.003 & 0.003 & 0.003 & 0.003 & 0.02 & 0.006 & 0.003 & 0.002 & 0.009 & 0.05 & 0.01 & 0.28 & 0.05 & 0.003 & 0.02 & 0.002 \\
\hline Se & 0.006 & 0.004 & 0.01 & 0.01 & 0.02 & 0.01 & 0.0009 & 0.008 & 0.02 & 0.02 & 0.02 & 0.16 & 0.01 & 0.01 & 0.01 & 0.01 \\
\hline Mo & 0.008 & 0.007 & 0.01 & 0.009 & 0.10 & 0.03 & 0.01 & 0.01 & 0.002 & 0.01 & 0.002 & 0.06 & 0.03 & 0.01 & 0.02 & 0.003 \\
\hline $\mathrm{Cd}$ & 0.002 & 0.001 & 0.01 & 0.006 & 0.006 & 0.007 & 0.001 & 0.001 & 0.004 & 0.01 & 0.001 & 0.02 & 0.02 & 0.002 & 0.002 & 0.002 \\
\hline $\mathrm{Pb}$ & 0.12 & 0.18 & 1.26 & 0.25 & 0.13 & 0.17 & 0.05 & 0.06 & 1.29 & 0.04 & 0.05 & 0.30 & 0.13 & 0.04 & 0.01 & 0.05 \\
\hline
\end{tabular}

AR-D. alata Raw; AB-D. alata Boiled; AS-D. alata Steamed; ARo-D. alata Roasted; PR-D. pentaphylla Raw; PB- $D$. pentaphylla Boiled; PS- $D$. pentaphylla Steamed; PRo-D. pentaphylla Roasted; OR-D. oppositifolia Raw; OB-D. oppositifolia Boiled; OS-D. oppositifolia Steamed; ORo-D. oppositifolia Roasted; PIR-Pl. rotundifolius Raw; PIB-Pl. rotundifolius Boiled; PIS-Pl. rotundifolius Steamed; PIRo-Pl. rotundifolius Roasted.

\section{Extract yield, total phenolics and tannins}

Plant parts having complex structure contain different groups of primary and secondary metabolites with a wide range of functional groups and polarities. As phenolic compounds are a highly varied group of secondary metabolites. Complete separation of these compounds needs undesirable time and high consumption of solvents [52]. The most commonly used and most effective solvents for extracting polyphenols from Dioscorea sp. are acetone, ethanol and methanol. In this study, ethanol was selected because of the lower toxic property and high polarity nature. Furthermore, ethanol yields more phenolic compounds as it selectively extracts low and high molecular weight polyphenols from plants [52].

For the purpose of obtaining extracts with the highest antioxidant activity as possible, without loss of active phytochemicals, the extraction procedure was carried out at room temperature. Along extraction time and uneconomical procedure are needed for the significant increases in the amount of phenols extracted. After testing different extraction times in previous studies (data not shown), an extraction time of $48 \mathrm{~h}$ under non-oxidative conditions was chosen to ensure a good yield and obtain extracts with the highest possible bioactivity. The extraction procedure requires a controlled stirring speed to prevent the formation of emulsions, make phase separation difficult and consequently increase the extraction yield.

Recovery is the main step for acquiring extracts with adequate yields and strong antioxidant activity. Each sample was extracted using a solvent system of $95 \%$ ethanol. The yield percentage, total phenolics and tannin content of both raw and processed samples of Dioscorea and Pl. rotundifolius tubers are represented in table 4. It is noticed that the highest extract yield $(16.67 \%)$ was obtained for $D$. alata and the lowest (9.33\%) was found in D. oppositifolia. From these results, it is observed clearly that, the addition of some amount of water enhances the extraction efficiency.

Phenolic compounds are present in plants, which are applied as major constituents of both human and animal diets [53]. Polyphenols make a major contribution to free radical scavenging capacities. Antioxidant activity is directly related to total phenolic content, which could be observed as a main sign of antioxidant properties of plant extracts [54-55]. Phenolic compounds can perform as antioxidants through mechanisms including both free radical scavenging and metal chelation. They also have anti-diabetic, anti-carcinogenic, anti-microbial, anti-allergic and anti-inflammatory activities [56-57].

The effects of ethanol in extracting polyphenols and antioxidants from the selected tubers were quantitatively measured and compared. Table 4 shows the total phenolic content (TPC) and tannin contents of solvent extractions from the samples. The outputs were expressed as mg TAE/g DW basis, so as to exclude the effect of moisture content to quantification. The amount of total phenolic varied in the samples of current study ranged from 186.39-774.10 $\mathrm{mg}$ of TAE/g extract. Results revealed that wild species of $D$. oppositifolia (774.10 mg of TAE/g extract) showed higher phenolic content than the cultivated variety Pl. rotundifolius $(244.10 \mathrm{mg}$ of $\mathrm{TAE} / \mathrm{g}$ extract). This may be assumed that the variation in TPC was characterized to various aspects including genotype, agronomic practices, post-harvest storage and, climatic and geographical locations. The wild species grow in organic environmental conditions, so it could be suggested that growing conditions have a certain effect on the synthesis and accumulation of phenolic compounds.

Tannins are major groups of antioxidant polyphenols, have attracted lot of interest for the reason that, their multifunctional properties advantageous to human well-being. They have been well thoughtout as cardioprotective, anti-inflammatory and antimutagenic agents [58]. The tannin content of samples was ranged from 136.82-727.69 mg TAE/g. Tannin content was also found to be higher in $D$. oppositifolia (727.69 mg of TAE/g extract) and the lowest value was recorded in boiled tubers of $D$. alata $(136.82 \mathrm{mg} \mathrm{TAE} / \mathrm{g})$. Tannins were compounded with organic compounds such as proteins, starches and digestive enzymes thus reduce the dietary importance of foods [59]. They inhibit protein absorption and reduce iron availability [60]. So, the minimum level of tannins in the diet is recommended.

\section{Total flavonoids}

Flavonoids comprise the most common group of plant polyphenols and provide flavour and colour. They are plant organic compounds that are not directly involved in metabolic activities, which including flavonols, flavones, flavanones and anthocyanins [61]. Flavonoids have received considerable attention in recent years due to their 
diverse pharmacological properties including antioxidant and antitumor activity [62]. They possess a number of phenolic hydroxyl groups attached to the carbon skeleton C6-C3-C6 structures characterized by a three-carbon aliphatic chain which normally has been condensed to form a pyran, or less commonly a furan ring conferring an antioxidant activity [63]. Most of the flavonoids are considered to be well-known antioxidants due to their electron or hydrogen donating capacity. The total flavonoid content (TFC) of raw and processed tubers of Dioscorea and Pl. rotundifolius is presented in table 4. TFC described as Rutin equivalent antioxidant capacity. All the samples have a lower amount of flavonoid when compared to total phenolics. The highest flavonoid content was found in D. oppositifolia (80.06 mg of RUE/g extract) and boiled tubers of $D$. alata have the lowest (50.51 mg of RUE/g extract).

In vitro and studies related to health and disease conditions were advised that the intake of diets with huge quantities of flavonoids will defend against human diseases for the reason that their freeradical scavenging activity also has defence mechanism contrary to oxidative stress [64].

Table 4: It shows phytochemical contents of plant samples

\begin{tabular}{|c|c|c|c|c|}
\hline Sample & $\begin{array}{l}\text { Extract yield } \\
(\%)\end{array}$ & $\begin{array}{l}\text { Total phenolicsa } \\
\text { (mg of TAE/g extract) }\end{array}$ & $\begin{array}{l}\text { Tannins } \\
\text { (mg of TAE/g extract) }\end{array}$ & $\begin{array}{l}\text { Total flavonoids } \\
\text { (mg of RUE/g extract) }\end{array}$ \\
\hline$\overline{A R}$ & 16.67 & $206.67^{i} \pm 4.61$ & $180.51^{\mathrm{h}} \pm 0.87$ & $55.75^{\mathrm{e}} \pm 0.08$ \\
\hline $\mathrm{AB}$ & 13.33 & $186.39^{\mathrm{k}} \pm 6.67$ & $136.82^{j} \pm 6.82$ & $50.51^{\mathrm{g}} \pm 0.70$ \\
\hline AS & 10.00 & $191.54 j \pm 6.41$ & $141.80^{i} \pm 6.51$ & $52.89^{f} \pm 0.43$ \\
\hline ARo & 13.33 & $193.03^{j} \pm 6.15$ & $147.18^{\mathrm{i} \pm 5.48}$ & $50.99 \mathrm{~g} \pm 0.63$ \\
\hline PR & 13.33 & $576.67^{c} \pm 6.59$ & $536.15^{c} \pm 5.23$ & $74.81^{b} \pm 0.29$ \\
\hline PB & 13.33 & $562.30^{\mathrm{d}} \pm 6.92$ & $513.59^{\mathrm{d}} \pm 6.84$ & $62.90^{\mathrm{d}} \pm 0.83$ \\
\hline PS & 10.00 & $556.23^{\mathrm{e}} \pm 7.39$ & $506.33^{\mathrm{e}} \pm 7.33$ & $66.23^{c} \pm 0.52$ \\
\hline PRo & 10.00 & $569.23^{\mathrm{d}} \pm 6.67$ & $519.77^{\mathrm{d}} \pm 5.74$ & $73.86^{\mathrm{b}} \pm 0.46$ \\
\hline OR & 9.33 & $774.10^{\mathrm{a}} \pm 2.53$ & $727.69^{a} \pm 0.61$ & $80.06^{\mathrm{a}} \pm 0.04$ \\
\hline OB & 13.33 & $753.85^{\mathrm{b}} \pm 7.64$ & $701.80^{\mathrm{b}} \pm 7.30$ & $71.95^{b} \pm 0.25$ \\
\hline OS & 11.33 & $754.54^{\mathrm{b}} \pm 4.61$ & $705.39^{b} \pm 3.94$ & $71.48^{\mathrm{b}} \pm 0.90$ \\
\hline ORo & 12.67 & $759.49^{b} \pm 3.79$ & $708.72^{\mathrm{b}} \pm 0.87$ & $72.91^{\mathrm{b}} \pm 0.21$ \\
\hline PIR & 13.33 & $244.10^{f} \pm 6.64$ & $204.10^{\mathrm{f}} \pm 3.43$ & $65.76^{c} \pm 0.08$ \\
\hline PIB & 11.33 & $229.23^{g} \pm 6.69$ & $189.74^{\mathrm{g}} \pm 3.69$ & $61.95^{\mathrm{d}} \pm 0.80$ \\
\hline PIS & 12.67 & $223.74^{\mathrm{h}} \pm 7.49$ & $173.90^{\mathrm{h}} \pm 6.56$ & $62.42^{\mathrm{d}} \pm 0.39$ \\
\hline PIRo & 12.00 & $225.28^{\mathrm{g}} \pm 6.51$ & $172.31^{\mathrm{h}} \pm 6.58$ & $64.81^{\mathrm{d}} \pm 0.15$ \\
\hline
\end{tabular}

AR-D. alata Raw; AB-D. alata Boiled; AS- $D$. alata Steamed; ARo- $D$. alata Roasted; PR- $D$. pentaphylla Raw; PB- $D$. pentaphylla Boiled; PS- $D$. pentaphylla Steamed; PRo-D. pentaphylla Roasted; OR-D. oppositifolia Raw; OB-D. oppositifolia Boiled; OS-D. oppositifolia Steamed; ORo-D. oppositifolia Roasted; PIR-Pl. rotundifolius Raw; PIB-Pl. rotundifolius Boiled; PIS-Pl. rotundifolius Steamed; PIRo-Pl. rotundifolius Roasted., Each

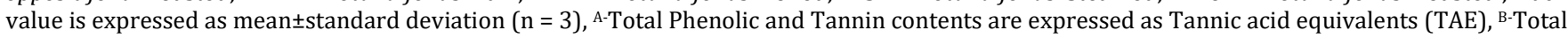
Flavonoid contents are expressed as Rutin equivalents (RUE)

\section{Screening of antioxidant activity using DPPH method}

DPPH radical scavenging activity was examined in each sample with reference to inhibition ability of a pre-formed free radical by antioxidants. DPPH assay is one of the most extensively used methods for monitoring the antioxidant activity of plant extracts and food samples. The assay is based on the extents of the antioxidant's ability to scavenge the stable radical of DPPH. DPPH is a stable nitrogen-centred free radical, has an unpaired valence electron at one atom of Nitrogen Bridge [65].

As this electron is paired off in the presence of a free radical scavenger, absorption vanishes and the resulting decolouration is stoichiometric with respect to the number of electrons taken up. This bleaching of DPPH, which occurs when the odd electron of the radical is paired, is thus representative of the capacity of the compounds to scavenge free radicals independently on any enzymatic activity [66]. Antioxidant activity of the raw tuber species as determined by DPPH scavenging method decreased in the order: D. oppositifolia (4601.89 mmol TE/g extract) $>D$. pentaphylla (3348.61 mmol TE/g extract) $>D$. alata $(2870.12 \mathrm{mmol} \mathrm{TE} / \mathrm{g}$ extract) $>$ Pl. rotundifolius (2110.59 mmol TE/g extract).

Results revealed that DPPH scavenging effects significantly declined with various processing treatments (table 5). Raw yams of all species had the highest DPPH scavenging effects among all processing treatments but were lower than natural and synthetic antioxidants. Raw yams contained significantly higher total phenolic contents than processed yams (table 4) and followed a similar trend to that of DPPH. Boiling showed higher DPPH scavenging effect than other processing methods. Among processing methods, boiling appeared to retain more total phenolic compounds. The solvent used for the extraction of antioxidant compounds play a major role for DPPH radical scavenging activity. It is confirmed that not only the quantity of individual components but also the presence of different compounds have influenced the radical scavenging activity.

\section{Total antioxidant activity using $\mathrm{ABTS}^{++}$radical cation decolorization assay}

DPPH is often used in the evaluation of free radical scavenging ability; though, it has the drawback of colour interference and sample solubility. Hence, free radical scavenging ability of the tuber extracts was additionally studied using a temperately stable nitrogen-centred radical species, $\mathrm{ABTS}^{+}$. The $\mathrm{ABTS}^{+}$radical based model of free radical scavenging capacity has the benefit of being extra flexible, at the same time both non-polar and polar samples can be evaluated, and spectral hindrance is minimized and the absorption maximum used is $760 \mathrm{~nm}$ [67]. The ABTS assay has been commonly used to assess antioxidant activities of constituents in foods and beverages because of its relevance in aqueous and lipid phases. The original ABTS.+ assay was based on the activation of metmyoglobin by hydrogen peroxide in the presence of ABTS [68]. In the advanced version of this test, a stable $\mathrm{ABTS}^{+}$radical cation, which has blue-green chromophore absorption, was produced before the adding up of antioxidants as a result of the oxidation of ABTS with Potassium persulphate [29]. The $\mathrm{ABTS}^{+{ }^{+}}$radical cation is more reactive than DPPH. Radical and reaction of ABTS ${ }^{+}$radical with an antioxidant will complete within $1 \mathrm{~min}$ [69].

Antioxidant capacity by $\mathrm{ABTS}^{++}$assay was consistently higher than DPPH. assay in the total sample. Among the tuber samples studied, $D$. oppositifolia (15745.90 mmol TE/g extract) showed the highest antioxidant activity followed by $D$. alata $(15129.07 \mathrm{mmol} \mathrm{TE} / \mathrm{g}$ extract) Pl. rotundifolius $(15036.53 \mathrm{mmol} \mathrm{TE} / \mathrm{g}$ extract $)$ and $D$. pentaphylla (14851.44 mmol TE/g extract). However, the wild species have more radical scavenging activity. The absorbance of the reaction mixture of ABTS and an antioxidant is compared to that of Trolox standard, and results are indicated in terms of TEAC. 


\section{Ferric reducing antioxidant power assay}

The reducing capacity of a compound may serve as a significant indicator of its potential antioxidant activity. Reducing power is a novel antioxidant ion protection method which is influenced by electron and hydrogen atom transfer [70]. The ferric reducing/antioxidant power is an easy and shortest test of assessing antioxidant capacity [71]. This assay determines the electron-donating capability of antioxidants using potassium ferricyanide reduction method. Antioxidant compounds reduce the ferric ion/ferricyanide complex to ferrous form [72] and they act as reducing agents by giving a hydrogen atom to this ferric complex, as a result breaking the radical chain reaction [73]. The $\mathrm{Fe}^{2+} \mathrm{can}$, therefore, be monitored by measuring the formation of Perl's Prussian blue at $700 \mathrm{~nm}$ [74].

Table 5 shows the reducing power of raw and processed tuber extracts. Among the tuber, sp studied, more reducing power recorded for D. oppositifolia (10701. $37 \mathrm{mmol} \mathrm{Fe} \mathrm{(II)/g} \mathrm{extract)} \mathrm{than} \mathrm{others.} \mathrm{The}$ antioxidant activity has been reported to be concomitant with the development of reducing power [75]. The enhanced level of total reductant ability in processed samples monitored in the current study is in good agreement with the earlier reports [76] wherein it is observed that thermal processing is completely conserved the biologically active compounds(polyphenols, flavonoids, flavonols and tannins)and total antioxidant capacity. The enhanced reducing activity in processed samples was justified by reason of the formation of redox-active secondary metabolites (Maillard reaction and Amadori rearrangement products) and the breaking of composite phenolic compounds at high temperature became soft or causing distraction of plant cell walls [77]. Their elevated activities are also aligned with TPC. In addition, flavonoid derivatives may be accountable for the enhancement of reducing the power of the extracts.

\section{Metal chelating activity}

The assay was employed to find out the chelating activity of $\mathrm{Fe}^{2+}$. It was based on the chelation of metal ion $\left(\mathrm{Fe}^{2+}\right)$ with ferrozine to give a red coloured complex. Ferrozine can form complexes by means of quantity with $\mathrm{Fe}^{2+}$. In the presence of other chelating agents, the development of complex is disturbed; consequently, the red colour of the complex is dropped off. As a result, measurement of the rate of colour reduction permits evaluation of chelating activity of the coexisting chelator [78]. A promising connection among total flavonoids and Fe-chelating activity was suggested in an earlier study [79]. The results expose that all the extracts were interfered with the formation of ferrous and ferrozine complex, suggesting that they have chelating activity and are able to capture ferrous ion before ferrozine. In accordance with above-mentioned assays, potent chelation abilities were again detected in $D$. oppositifolia (2.44 mg EDTA/g extract), compared to others. The lowest activity was registered for $D$. pentaphylla roasted tubers (1.42 mg EDTA/g extract). Processing caused a significant decline in ferrous ion chelating capacity among yams (table 5). Steaming apparently retained more chelating capacity than other processing methods, while high-temperature processing (deep frying) caused the greatest loss in chelating capacity.

Chelating agents creates $\sigma$-bonds with a metal, and they reduce the redox potential hence stabilizing the oxidized form of the metal ion; for the reason that, they are efficient as secondary antioxidants [80]. The development in the Fe (II) chelating ability is related to that of DPPH radical scavenging, $\mathrm{ABTS}^{+\cdot}$ radical scavenging capacity and reducing power. The total antioxidant capacity is a combination of diverse antioxidant mechanism, comprising free radical scavenging ability, reducing power and Fe (II) chelating ability [67].

Table 5: It shows antioxidant activity of tubers

\begin{tabular}{|c|c|c|c|c|}
\hline Sample & ABTS A & DPPH $^{A}$ & FRAP B & Metal Chelating $\mathrm{C}$ \\
\hline $\mathrm{AR}$ & $15129.07^{b} \pm 218.66$ & $2870.12^{\mathrm{f}} \pm 0.44$ & $8856.25^{\mathrm{c}} \pm 136.06$ & $1.71^{\mathrm{c}} \pm 0.01$ \\
\hline $\mathrm{AB}$ & $12209.61^{\mathrm{e}} \pm 527.49$ & $2824.57^{f} \pm 2.74$ & $6951.45^{\mathrm{d}} \pm 242.71$ & $1.27 \mathrm{e} \pm 0.02$ \\
\hline AS & $14789.67 \mathrm{~b} \pm 230.91$ & $2750.29^{g} \pm 5.76$ & $7009.70^{\mathrm{d}} \pm 216.35$ & $1.70^{c} \pm 0.01$ \\
\hline ARo & $14309.37 \mathrm{c} \pm 240.19$ & $2772.66^{\mathrm{g}} \pm 4.28$ & $7029.12^{\mathrm{d}} \pm 213.78$ & $1.69^{\mathrm{c}} \pm 0.01$ \\
\hline PR & $14851.44^{\mathrm{b}} \pm 277.33$ & $3348.61^{\mathrm{d}} \pm 2.73$ & $9031.29^{b} \pm 126.21$ & $1.86^{\mathrm{b}} \pm 0.01$ \\
\hline PB & $13450.48^{\mathrm{d}} \pm 487.22$ & $3331.62^{\mathrm{d}} \pm 7.36$ & $8388.34^{c} \pm 188.34$ & $1.70^{\mathrm{c}} \pm 0.01$ \\
\hline PS & $13573.80^{\mathrm{d} \pm 280.38}$ & $3273.93^{\mathrm{e}} \pm 5.05$ & $7126.21^{\mathrm{d}} \pm 251.45$ & $1.85^{\mathrm{b}} \pm 0.01$ \\
\hline PRo & $11931.84 \mathrm{e} \pm 499.27$ & $3228.99 \mathrm{e} \pm 8.11$ & $8893.20^{\mathrm{b}} \pm 159.22$ & $1.42^{\mathrm{d}} \pm 0.02$ \\
\hline OR & $15745.90^{\mathrm{a}} \pm 258.85$ & $4601.89 \mathrm{a} \pm 2.04$ & 10701. $37^{\mathrm{a} \pm 164.07}$ & $2.44^{\mathrm{a}} \pm 0.01$ \\
\hline $\mathrm{OB}$ & $12825.02^{\mathrm{d}} \pm 517.03$ & $4567.67^{b} \pm 5.83$ & $8796.11^{b} \pm 250.48$ & $1.88^{\mathrm{b}} \pm 0.01$ \\
\hline OS & $14067.30^{c} \pm 520.02$ & $4536.00^{\mathrm{b}} \pm 7.39$ & $8922.33^{b} \pm 213.59$ & $1.87^{b} \pm 0.01$ \\
\hline ORo & $14913.20^{\mathrm{b}} \pm 400.18$ & $4481.20^{c} \pm 8.94$ & $9291.26^{b} \pm 209.70$ & $1.84^{\mathrm{b}} \pm 0.02$ \\
\hline PIR & $15036.53^{\mathrm{b}} \pm 160.58$ & $2110.59 \pm 0.42^{\mathrm{h}}$ & $8351.44^{c} \pm 160.19$ & $2.39^{a} \pm 0.01$ \\
\hline $\mathrm{PlB}$ & $12116.98 \mathrm{e} \pm 506.44$ & $1990.31^{\mathrm{i} \pm 8.87}$ & $7543.68^{\mathrm{d}} \pm 194.17$ & $1.82^{\mathrm{b}} \pm 0.01$ \\
\hline PIS & $14974.76^{b} \pm 250.32$ & $2034.63^{i} \pm 1.95$ & $6446.60^{e} \pm 237.86$ & $1.83^{\mathrm{b}} \pm 0.01$ \\
\hline PlRo & $14728.11^{\mathrm{b}} \pm 470.79$ & $2030.82^{i} \pm 6.55$ & $7097.08^{\mathrm{d}} \pm 232.03$ & $1.81^{\mathrm{b}} \pm 0.02$ \\
\hline \multicolumn{5}{|c|}{ Standards } \\
\hline BHA & $655137.0 \pm 61415.9$ & $788083.1 \pm 39261.0$ & $350760.4 \pm 72476.7$ & $10.5 \pm 0.6$ \\
\hline Rutin & $433569.1 \pm 23178.3$ & $752247.3 \pm 7364.2$ & $174032.8 \pm 26869.7$ & - \\
\hline TAN & $751041.70 \pm 632.30$ & $848540.10 \pm 547.00$ & $565217.40 \pm 427.70$ & - \\
\hline
\end{tabular}

AR-D. alata Raw; AB-D. alata Boiled; AS-D. alata Steamed; ARo-D. alata Roasted; PR-D. pentaphylla Raw; PB- $D$. pentaphylla Boiled; PS- $D$. pentaphylla Steamed; PRo-D. pentaphylla Roasted; OR-D. oppositifolia Raw; OB-D. oppositifolia Boiled; OS-D. oppositifolia Steamed; ORo-D. oppositifolia Roasted; PIR-Pl. rotundifolius Raw; PIB-Pl. rotundifolius Boiled; PIS-Pl. rotundifolius Steamed; PIRo-Pl. rotundifolius Roasted, Each value is expressed as mean \pm standard deviation $(\mathrm{n}=3$ )., A: mmol Trolox equivalent antioxidant capacity (TEAC)/g extract, B: mmol Fe (II) equivalent/g extract, C: mg EDTA equivalent/g extract, BHA-Butylated Hydroxy Anisole, TAN-Tannic Acid

\section{CONCLUSION}

Yam (Dioscorea sp.) has been reported to possess many functional properties and is regarded as a healthy food. The current study is a novel approach to reveal the antioxidant potential and nutritional benefits of underutilized species of Dioscorea, and comparison with a commodity crop Pl. rotundifolius. The study also focused on the influence of processing methods on their proximate composition, mineral profile, phytochemical contents as well as the effect on their antioxidant potential.
The food elements with a high level of phenolic content revealed comparatively greater antioxidant activity. The present study suggests that yams are important as food and as nutraceutical agents, and we hereby report the identification of yam with high antioxidant activities in their tubers.

The ethanolic extract of Dioscorea oppositifolia elicited strong antioxidant activity in various in vitro systems tested. The antioxidant effect may be due to the phenolic and flavonoids present in it. 
For these reasons, promotion and probably profit-orientation of these tubers ought to been encouraged and delivered for wider consumption. Advance research is supposed to consider next to antioxidant activity along with various physiological effects of cooked tuber varieties. This study seems to be useful for the future exploitation of traditional knowledge to develop novel functional food for safeguarding our health. In conclusion, the high antioxidant activity exhibited by Dioscorea extracts provided justification for the therapeutic use of this plant in folkloric medicine due to the phytochemical constituents. Since reactive oxygen species are important contributors to several serious ailments, the present data suggest that Dioscorea extracts could be useful for the development of newer and more potent natural antioxidants, which could be of great importance for the treatment of radical related diseases and age-associated diseases.

\section{CONFLICT OF INTERESTS}

We wish to confirm that there are no known conflicts of interest associated with this publication and there has been no significant financial support for this work that could have influenced its outcome.

\section{REFERENCES}

1. Asha KI, Nair MC. Ethnic knowledge system on wild Dioscorea (yams) by the Kanikkars of Southern Western Ghats, Kerala. Indian J Plant Genet Res 2002;15:146-9.

2. Pedralli G, Carmo CAS, Cereda M, Puiatti M. Uso de nomes populares para as espécies de Araceae e Dioscoreaceae no Brasil. Hortic Bras 2002;20:530-2.

3. Pedralli G. Flora ilustrada catarinense. Fundação Cultural de Itajaí. Santa Catarina; 2004.

4. Nassar N. Cassava in South America, Brazil's contribution and the lesson to be learned from India. Genet Mol Res 2006b;5:688-95.

5. Nindjin C, Otokoré D, Hauser S, Tschannen A, Farah Z, Girardin 0 . Determination of relevant sensory properties of pounded yams (Dioscorea spp.) using a locally based descriptive analysis methodology. Food Quality Pref 2007;18:450-9.

6. Hou WC, Mei-Hsien Lee, Chen HJ, Wen-Lee Liang, Han CH, YenWenn Liu, et al. Antioxidant activities of dioscorin, the storage protein of yam (Dioscorea batatas Decne) tuber. J Agric Food Chem 2001;49:4956-60.

7. Lu YL, Cho-Yun Chia, Liu Y W, Wen-Chi Hou. Biological activities and applications of dioscorins, the major tuber storage proteins of yam. Afr J Tradit Complementary Altern Med 2012;2:41-6.

8. Hsu FL, Lin YH, Lee MH, Lin CL, Hou WC. Both dioscorin, the tuber storage protein of yam (Dioscorea alata cv. Tainong $\mathrm{Nr}$ 1), and its peptic hydrolysates exhibited angiotensin converting enzyme inhibitory activities. J Agric Food Chem 2002;50:6109-13.

9. Kay DE. Root Crops. TPI Crop and Product Digest, Overseas Development Agency, London; 1973.

10. Bayani Uttara, Ajay V Singh, Paolo Zamboni, Mahajan RT. Oxidative stress and neurodegenerative diseases: a review of upstream and downstream antioxidant therapeutic options. Curr Neuropharmacol 2009;7:65-74.

11. Young S, Woodside JVJ. Antioxidants in health and disease. Clin Pathol 2001;54:176-86.

12. Badarinath AV, Rao KM, Chetty CMS, Ramkanth S, Rajan TVS, Gnanaprakash K. A review on in vitro antioxidant methods: comparisons, correlations and considerations. Int J PharmTech Res 2010;2:1276-8.

13. Rizvi, Kanti Bhooshan Pandey, Syed Ibrahim. Plant polyphenols as dietary antioxidants in human health and disease. Oxid Med Cell Longevity 2009;5:270-8.

14. Ali SS, Kasoju N, Luthra A, Singh A, Sharanabasava H, Sahu A, et al. Indian medicinal herbs as sources of antioxidants. Food Res Inter 2008;41:1-15.

15. Ajith TA, Janardhanan KK. Antioxidant and antihepatotoxic activities of Phellinus rimosus (Berk) pilat. J Ethnopharmacol 2002;81:387-91.

16. Anupam G, Bidus KD, Soroj KC, Goutam C. Antibacterial potentiality and phytochemical analysis of mature leaves of Polyalthialongifolia (Magnoliales: Annonaceae). South Pacific J Natural Sci 2008;26:68-72.
17. Anand PK, Policegoudra RS, Aradhya SM. Chemical composition and antioxidant activity of Sapota (Achrassapotalinn.) fruit. J Food Biochem 2007;31:399-414.

18. Magbagbeola JAO, Adetoso JA, Owolabi OA. Neglected and underutilised species (NUS): a panacea for community-focused development to poverty alleviation/poverty reduction in Nigeria. J Economics Int Finance 2010;2:208-11.

19. Janick J. Editor. Padulosi S, Eyzaquirre P, Hodgkin T. Challenges and Strategies in Promoting Conservation and Use of Neglected and Underutilized Crop Species. ASHS Press, Alexandria, Va, USA; 1999.

20. Johns T, Eyzaguirre PB. Symposium on "wild gathered plants: basic nutrition, health and survival" Linking biodiversity, diet and health in policy and practice," Proc Nutr Soc 2006;65:182-9.

21. Ghane SG, Lokhande $\mathrm{VH}$, Ahire ML, Nikam TD. Indigofera glandulosa Wendl. (Barbada) a potential source of nutritious food: underutilized and neglected legume in India. Genet Resour Crop Evol 2010;57:147-53.

22. Frison E, Omont H, Padulosi S. GFAR and international cooperation on commodity chains. synthesis paper for presentation to the GFAR-2000 Conference, Dresden, Germany; 2000. p. 21-23.

23. FAO (Food and Agriculture Organization of the United Nations). Production indices and Pop STAT. FAO, Statistics Division; 2009. Available from: http://faostat.fao.org/default.aspx. [Last accessed on 08 Dec 2009]

24. AOAC. Official Methods of Analysis. $14^{\text {th }}$ ed. Washington DC: Association of Official Analytical Chemists; 1990.

25. Siddhuraju P, Vijayakumari K, Janardhanan K. Chemical composition and nutritional evaluation of an underexploited legume, Acacia nilotica (L.) Del. Food Chem 1996;57:385-91.

26. Yu L, Haley S, Perret J, Harris M, Wilson J, Qian M. Free radical scavenging properties of wheat extracts. J Agric Food Chem 2002;50:1619-24.

27. Makkar HPS, Francis G, Becker K. Bioactivity of phytochemicals in some lesser-known plants and their effects and potential applications in livestock and aquaculture production systems. Animal 2007;1:1371-91.

28. Siddhuraju P, Becker K. Antioxidant properties of various solvent extracts of total phenolic constituents from three different agroclimatic origins of Drumstick tree (Moringa olifera Lam.) leaves. J Agric Food Chem 2003;51:2144-55.

29. Re R, Pellegrini N, Proteggente A, Pannala A, Yang M, RiceEvans E. Antioxidant activity applying an improved ABTS radical cation decolonization assay. Free Radical Biol Med 1999;26:1231-7.

30. Blois MS. Antioxidant determination by the use of a stable free radical. Nat 1958;181:1199-200.

31. Brand-Williams W, Cuvelier ME, Berset C. Use of a free radical method to evaluate antioxidant activity. LWT-Food Sci Technol 1995;28:25-30.

32. Pulido R, Bravo L, Saura-Calixto F. Antioxidant activity of dietary polyphenols as determined by a modified ferric reducing/antioxidant power assay. J Agric Food Chem 2000;48:3396-402.

33. Dinis TCP, Madeira VMC, Almeida LM. The action of phenolic derivatives (acetaminophen and as peroxyl radical scavengers. Arch Biochem Biophys 1994;315:161-9.

34. Udensi EA, Oselebe HO, Iweala OO. The investigation of chemical composition and functional properties of water yam (Dioscorea alata): effect of varietal differences. Pak J Nutr 2008;7:342-4.

35. Iheanacho K, Ubebani AC. Nutritional composition of some leafy vegetable consumed in Imo State. JASEM 2009;13:35-8.

36. Kwenin WKJ, Wolli M, Dzomeku BM. Assessing the nutritional value of some African indigenous green leafy vegetables in Ghana. J Anim Plant Sci 2011;10:1300-5.

37. Afoakwa EO, Sefa-Dedeh S. Chemical composition and quality changes occurring in Dioscorea dumetorum pax tubers after harvest. Food Chem 2001;75:85-91.

38. Ramirez-Moreno E, Cordoba-Diaz D, de Cortes Sanchez-Mata M, Diez-Marques C, Goni I. Effect of boiling on nutritional, antioxidant and physicochemical characteristics in Cladodes (Opuntia ficus indica). LWT-Food Sci Tech 2013;51:296-302. 
39. Huang CC, Mei-Chen Lin, Chiun CR Wang. Changes in morphological, thermal and pasting properties of yam (Dioscorea alata) starch during growth. Carbohydrate Polymers 2006;64:524-31.

40. Oko AO, Famurewa AC. Estimation of nutritional and starch characteristics of Dioscorea alata (water yam) varieties commonly cultivated in the South-Eastern Nigeria. Br J Appl Sci Tech 2015;6:145-52.

41. Wanasundera PKJPD, Ravindran G. Nutritional assessment of yam (Dioscorea alata) tubers. Plant Foods Human Nutr 1994;46:33-9.

42. Gupta UC, Gupta SC. Sources and deficiency diseases of mineral nutrients in human health and nutrition: a review. Pedosphere 2014;24:13-38.

43. Demigne C, Sabboh H, Reme SC, Meneton P. Protective effects of high dietary potassium in nutritional and metabolic aspects. J Nutr 2004;134:2903-6.

44. Tapia MI, Sanchez-Morgado JR, Garcia-Parra J, Ramirez R, Hernandez T, Gonzalez-Gomez D. Comparative study of the nutritional and bioactive compounds content of four walnut (Juglans regia L.) cultivars. J Food Compost Anal 2013;31:232-7.

45. Lewu MN, Adebola PO, Afolayan AJ. Comparative assessment of the nutritional value of commercially available cocoyam and potato tubers in South Africa. J Food Quality 2010b;33:461-76.

46. Caidan R, Cairang L, Liu B, Suo Y. Amino acid, fatty acid and mineral compositions of fruit, stem, leaf and root of Rubus amabilis from the Quighai-Tibetan Plateau. J Food Compost Anal 2014;33:26-31.

47. Akpanyung EO. The proximate and mineral composition of bouillon cubes produced in Nigeria. Pak J Nutr 2005;4:327-9.

48. Bhaskaran P. Immunobiology of mild nutrient deficiency. Br J Nutr 2001;85:75-80.

49. Geissler CA, Powers HJ. Human nutrition. Elsevier, Churchill Livingstone 2005;11:236-43.

50. Anyoola PB, Adeyeye A, Onawumi 00. Trace element and a major evaluation of Spondias mombin, Veronia amygdalina and Momordia charantia leave. Pak J Nutr 2010;9:755-8.

51. Njoku PC, Ohia CC. Spectrophotometric estimation studies of mineral nutrient in three cocoyam cultivars. Pak J Nutr 2007;6:616-9.

52. Kenny 0, Smyth TJ, Hewage CM, Brunton NP. Antioxidant properties and quantitative UPLC-MS analysis of phenolic compounds from extracts of Fenugreek (Trigonella foenumgraecum) seeds and Bitter melon (Momordica charantia) fruit. Food Chem 2013;141:4295-302.

53. Crozier A, Kamiya Y, Bishop G, Yokota T. Biosynthesis of hormones and elicitor molecules. In: Buchanan BB, Gruissem $\mathrm{W}$, Jones RL. editors. Biochemistry and molecular biology of plants. American Society of Plant Physiologists, Rockville; 2000. p. 850-929.

54. Valdez LB, Alvarex S, Lores AS, Schoopfer F, Carreras MC, Poderoso JJ, et al. Reactions of peroxynitrite in the mitochondrial matrix. Free Radical Biol Med 2000;29:349-56.

55. Sowndhararajan K, Sun Chul Kang. Free radical scavenging activity from different extracts of leaves of Bauhinia vahlii Wight and Arn. Saudi J Biol Sci 2013;20:319-25.

56. Saidu AN, Mann A, Onuegbu CD. Phytochemical screening and hypoglycemic effect of aqueous Blighia sapida root bark extract on normoglycemic albino rats. Br J Pharm Res 2012;2:89-97.

57. Sasikumar JM, Maheshu V, Aseervatham GSB, Darsini DTP. In vitro antioxidant activity of Hedyotis corymbosa (L) Lam aerial plants. Indian J Biochem Biophy 2010;47:49-52.

58. Kumari M, Jain S. Tannins: an antinutrient with positive effect to manage diabetes. Res J Recent Sci 2012;1:70-3.

59. Serrano J, Pupponen-Pimia R, Dauer A, Aura AM, Saura-Calixto F. Tannins: current knowledge of food sources, intake, bioavailability and biological effects. Mol Nutr Food Res 2009;53:S310-S329.

60. Bravo L. Polyphenols: chemistry, dietary sources, metabolism, and nutritional significance. Nutr Rev 1994;56:317-33.

61. Manach C, Morand C, Gil-Izquierdo A. Polyphenols: food sources and bioavailability. Am J Clin Nutr 2004;79:727-47.
62. Mithraja MJ, Johnson Marimuthu Antonisamy, Mony Mahesh, Paul ZM, Solomon Jeeva. Phytochemical studies on Azolla pinnata R. Br., Marsilea minuta L. and Salvinia molesta Mitch. Asian Pacific J Trop Biomed 2011;1:S26-S29.

63. Espley R, Martens S. Health properties of apple and pear, in bioactives in fruit: health benefits and functional foods. Skinner M, Hunter D. editors. John Wiley and Sons Ltd, Oxford, UK; 2013. p. 542.

64. Nithiyanantham S, Selvakumar S, Siddhuraju P. Total phenolic content and antioxidant activity of two different solvent extracts from raw and processed legumes, Cicer arietinum L. and Pisum sativum L. J Food Compost Anal 2012;27:52-60.

65. Eklund PC, Langvik OK, Warna JP, Salmi TO, Willfor SM, Sjoholm RE. Chemical studies on antioxidant mechanisms and free radical scavenging properties of lignans. Org Biomol Chem 2005;3:3336-47.

66. Fauconneau B, Waffo-Teguo P, Huguet F, Barrier L, Decendit A, Merillon JM. Comparative study of radical scavenger and antioxidant properties of phenolic compounds from Vitis vinifera cell cultures using in vitro tests. Life Sci 1997;61:2103-10.

67. Adefegha SA, Oboh G. Cooking enhances the antioxidant properties of some tropical green leafy vegetables by steam cooking. J Food Process Pres 2011;35:615-22.

68. Miller JK, Brzezinska-Slebodzinska E, Madsen FC. Oxidative stress, antioxidants and animal function. J Diary Sci 1993;76:2812-23.

69. Pokorny J, Yanishlieva N, Gordon M. Antioxidants in food practical applications. Wood head publishing Ltd, Abington hall, Abington; 2001. p. 73.

70. Oboh G, Raddatz H, Henle T. Antioxidant properties of polar and non-polar extracts of some tropical green leafy vegetables. J Sci Food Agric 2008;88:2486-92.

71. Marghitas LA, Stanciu OG, Dezmirean DS, Bobis O, Popescu O, Bogdanov S, et al. In vitro antioxidant capacity of honeybeecollected pollen of selected floral origin harvested from Romania. Food Chem 2009;115:878-83.

72. Oueslatia S, Trabelsia N, Boulaabaa M, Legaultb J, Abdellya C, Ksouri R. Evaluation of antioxidant activities of the edible and medicinal Suaeda species and related phenolic compounds. Ind Crops Prod 2012;36:513-8.

73. Shakirin FH, Prasad KN, Ismail A, Yuon LC, Azlan A. Antioxidant capacity of underutilized Malaysian Canarium odontophyllum (dabai) Miq. Fruit J Food Compost Anal 2010;23:777-81.

74. Chung YC, Chang CT, Chao WW, Lin CF, Chou ST. Antioxidative activity and safety of the $50 \%$ ethanolic extract from red bean fermented by Bacillus subtilis IMR-NK1. J Agric Food Chem 2002;50:2454.

75. Afolabi C, Akinmoladun EO, Ibukun, Emmanuel Afor BL, Akinrinlola TR, Onibon AO, et al. Chemical constituents and antioxidant activity of alstoniaboonei. Afr J Biotech 2007:6:1197-201.

76. Gorinstein S, Jastrzebski Z, Leontowicz H, Leontowicz M, Namiesnik J, Najmanc K. Comparative control of the bioactivity of some frequently consumed vegetables subjected to different processing conditions. Food Control 2009;20:407-13.

77. Dini I, Tenore GC, Dini A. Effect of industrial and domestic processing on antioxidant properties of pumpkin pulp. LWTFood Sci Technol 2013;53:382-5.

78. Wu SJ, Ng LT. Antioxidant and free radical scavenging activities of wild bitter melon (Momordica charantia linn. var. abbreviate Ser.) in Taiwan. LWT-Food Sci Technol 2008;41:323-30.

79. Loizzo MR, Tundis R, Bonesi M, Menichini F, Mastellone V, Avallone L. Radical scavenging, antioxidant and metal chelating activities of Annona cherimola Mill. (Cherimoya) peel and pulp in relation to their total phenolic and total flavonoid contents. J Food Compost Anal 2012;25:179-84.

80. Khanam UKS, Oba S, Yanase E, Murakami Y. Phenolic acids, flvonoids and total antioxidant capacity of selected leafy vegetables. J Funct Food 2012;4:979-87.

\section{How to cite this article}

- Jenit K Joy, P Siddhuraju. Studies on nutritional profile and antioxidant potential of different Dioscorea sp with Plectranthus rotundifolius. Int J Curr Pharm Res 2017;9(4):65-74. 